\title{
Effect of Cigarette Circumference on Formation Rates of various Components in Mainstream Smoke*
}

\author{
by T. Yamamoto, Y. Suga, C. Tokura, T. Toda and T. Okada \\ Central Research Institute, Japan Tobacco Inc., Yokohama, Japan
}

\section{SUMMARY}

Using cigarettes of different circumference but a constant packing density, the effect of circumference on the rate of formation (ratio of total delivery to the weight loss of tobacco during puffs) of various components was investigated. The rates of formation of $\mathrm{CO}$ and $\mathrm{HCN}$ increased and that of $\mathrm{B}[a] \mathrm{P}$ decreased with decreasing circumference, while those of $\mathrm{CO}_{2}, \mathrm{NO}$ and vapour phase $\mathrm{CH}_{3} \mathrm{CHO}$ were independent of circumference. The differences in the effect of circumference on the rate of formation of $\mathrm{CO}, \mathrm{B}[\mathrm{a}] \mathrm{P}$ and $\mathrm{HCN}$ can be explained by differences in their thermal formation during puffs.

\section{ZUSAMMENFASSUNG}

Unter Verwendung von Zigaretten gleicher Füldichte und verschiedenen Umfangs wurde untersucht, inwieweit die Bildung einiger Rauchinhaltsstoffe (d. $h$. die Gesamtausbeute im Verhältnis zum Gewichtsverlust des Tabaks während der Zūge) quantitativ durch den Zigarettenumfang beeinflußt wird. Verringerte sich der Umfang, so bildete sich mehr CO und HCN und weniger $\mathrm{B}[a] \mathrm{P}$, während die Mengen an $\mathrm{CO}_{2}, \mathrm{NO}$ und an in der Gasphase befindlichem $\mathrm{CH}_{3} \mathrm{CHO}$ von Veränderungen des Umfangs unabhängig waren. Die bei der Bildung von $\mathrm{CO}, \mathrm{B}[a] \mathrm{P}$ und $\mathrm{HCN}$ zu beobachtende unterschiedliche Einwirkung des Umfangs könnte damit erklärt werden, $\mathrm{daß}$ die einzelnen Verbindungen während der Züge durch verschiedenartige thermische Prozesse entstehen.

\footnotetext{
* Received: 26th February 1985 - accepted: 10th July 1985.
}

\section{RESUME}

En utilisant des cigarettes de même densité de remplissage mais de diamètres différents, on a étudié l'effet du diamètre de la cigarette sur le taux de formation (rendement total par rapport à la perte de poids du tabac pendant les bouffées) de différents composés. Lorsque le diamètre diminue, il se forme davantage de $\mathrm{CO}$ et de $\mathrm{HCN}$ et moins de $\mathrm{B}[a] \mathrm{P}$ tandis que les quantités de $\mathrm{CO}_{2}$, NO et de $\mathrm{CH}_{3} \mathrm{CHO}$ contenues dans la phase gazeuse sont indépendantes des modifications que subit le diamètre. Les différences observées en ce qui concerne la formation de $\mathrm{CO}, \mathrm{B}[a] \mathrm{P}$ et $\mathrm{HCN}$ peuvent s'expliquer par le fait que les divers composés sont produits pendant les bouffées par des processus thermiques différents.

\section{INTRODUC'TION}

In the previous paper, it was reported that the total delivery of tar and nicotine (i.e. the sum of the amount in mainstream smoke and that trapped on the filter and the tobacco column) changed proportionally with the loss in weight of the tobacco during puffs (1). This finding implies that the rate of formation (i,e. the ratio of total delivery to weight loss of tobacco during puffs) is independent of the circumference of the cigarette. Since the weight loss during puffs was proportional to the cross-sectional area of a cigarette with a constant packing density, it became possible to estimate the amount of tar and nicotine in mainstream smoke from the weight per unit length of cigarettes with different circumferences.

The rate of formation of a smoke component during a puff is an important factor in estimating the amount of 
Table 1.

Physical variables of tobacco columns and acetate filters.

\begin{tabular}{|c|c|c|c|c|c|}
\hline \multirow{2}{*}{$\begin{array}{l}\text { Circumference } \\
\text { (mm) }\end{array}$} & \multicolumn{2}{|c|}{ Tobacco column (65 mm) } & \multicolumn{3}{|c|}{ Filter $(20 \mathrm{~mm})$} \\
\hline & $\begin{array}{l}\text { Weight } \\
\text { (g) }\end{array}$ & $\begin{array}{l}\text { Pressure drop } \\
\left(\mathrm{mm} \mathrm{H}_{2} \mathrm{O}\right)\end{array}$ & $\begin{array}{c}\text { Weight } \\
\text { (g) }\end{array}$ & $\begin{array}{l}\text { Pressure drop } \\
\left(\mathrm{mm} \mathrm{H}_{2} \mathrm{O}\right)\end{array}$ & $\begin{array}{c}\text { Fractional } \\
\text { volume }\end{array}$ \\
\hline 21.1 & $0.682 \pm 0.01$ & $79.9 \pm 3$ & 93.7 & $66 \pm 2$ & 0.087 \\
\hline 22.9 & $0.797 \pm 0.01$ & $66.4 \pm 3$ & 117.6 & $66 \pm 2$ & 0.093 \\
\hline 25.0 & $0.948 \pm 0.01$ & $53.9 \pm 3$ & 149.2 & $66 \pm 2$ & 0.101 \\
\hline 25.8 & $1.010 \pm 0.01$ & $50.5 \pm 3$ & 164.0 & $66 \pm 2$ & 0.103 \\
\hline
\end{tabular}

Packing density of each tobacco column is $0.281 \mathrm{~g} / \mathrm{cm}^{3}$.

that component in mainstream smoke. The present paper describes the effect of circumference on the rate of formation of carbon oxide $\left(\mathrm{CO}, \mathrm{CO}_{2}\right)$, nitric oxide (NO), vapour phase acetaldehyde (v.p. $\mathrm{CH}_{3} \mathrm{CHO}$ ), benzo[a]pyrene $(\mathrm{B}[\mathrm{a}] \mathrm{P})$, and hydrogen cyanide $(\mathrm{HCN})$, which will be discussed in relation to differences in their thermal formation during puffs.

\section{MATERIALS AND METHODS}

\section{Cigarette Samples}

The cigarettes used were of a Virginia blend type and were the same as those used in the previous study (1). The physical variables of the tobacco column and the acetate filter $(2 \mathrm{~cm}$ length) are shown in Table 1 . The sample cigarettes were smoked, their weight and pressure drop measured and their smoke components analyzed at $22{ }^{\circ} \mathrm{C}$ and $60 \%$ relative humidity.

\section{Determination of Smoke Components}

Cigarettes were smoked on a smoking machine (Filtrona, model 302) under standard smoking conditions. The total particulate matter (TPM) was trapped on a Cambridge filter pad and the gas phase, which passed through the filter pad, was collected in a bag. The gas phase was introduced into a non-dispersive infrared analyzer, and the concentrations of $\mathrm{CO}$ and $\mathrm{CO}_{2}$ were measured. Vapour phase $\mathrm{CH}_{3} \mathrm{CHO}$ was determined by gas chromatography, as reported previously (2). The $\mathrm{NO}_{x}$ concentration in the mainstream smoke was determined on a chemiluminescence analyzer (Yanaco, $\mathrm{ECL}-77(\mathrm{v})$ type). Since the $\mathrm{NO}_{\mathrm{x}}$ in mainstream smoke is almost all nitric oxide (NO), hereafter $\mathrm{NO}_{\mathrm{x}}$ will be referred to simply as NO. The amount of $\mathrm{B}[\mathrm{a}] \mathrm{P}$ in the TPM trapped on the Cambridge filter pad was measured by means of fluorescence HPLC with a Nucleosil ${ }^{\circ} 7 \mathrm{C}_{18}$ column (Macherey-Nagel) using benzo[ $k]$ fluoranthene as internal standard (3).

$\mathrm{HCN}$ in mainstream smoke, in both the vapour and the particulate phases, was trapped in $75 \mathrm{ml}$ of a $0.5 \%$ $\mathrm{NaOH}$ solution. An aliquot of the solution was mixed with an equal amount of isoamyl alcohol. After being shaken, the mixture separated into two portions: an $\mathrm{NaOH}$ solution containing $\mathrm{HCN}$ and an isoamyl alcohol solution containing substances which prevent analysis. The concentration of $\mathrm{HCN}$ in the solution was colorimetrically determined by the pyridine-pyrazolone method (4).

\section{Total Deliveries of Smoke Components}

Total deliveries of the gas components $\mathrm{CO}, \mathrm{CO}_{2}$ and NO were determined by considering the loss due to diffusion through the cigarette paper. Generally, the equation $C_{1}=C_{0} e^{-D_{i} I}$ has been used when the linear gas velocity in a cigarette with ordinary cigarette paper can be considered constant (5-8), where $C_{0}$ and $C_{1}$ are the concentrations of the gas at the inlet and outlet of the cigarette, respectively, $\mathrm{L}$ is the length of cigarette in contact with the air, and $D_{i}$ is the coefficient of diffusion per unit length of the cigarette. In the present experiment, a cigarette was puffed when the normal cone was formed after ignition. After some static burn, the cigarette was again puffed. This procedure was repeated four times per cigarette. The length of the butt in contact with the air after completion of each puff was measured with a vernier caliper. The concentrations of $\mathrm{CO}, \mathrm{CO}_{2}$ and $\mathrm{NO}$ corresponding to each puff were measured. As a typical example, the relationship between the logarithmic values of the concentration of components in the gas and the length of the butt $(L)$ is shown in Figure 1. From the linear relationship between them, equation $C_{1}=C_{0} e^{-D_{i} L}$ was verified for cigarettes of each circumference. The concentration of components in the gas formed during a puff $\left(\mathrm{C}_{0}\right)$ was obtained from the intercept of each regression line. Strictly speaking, the amount of components in the gas during a puff $\left(C_{p}\right)$ which is calculated from $C_{0}$ is not considered to be quite constant as burning progresses, even in a cigarette with ordinary cigarette paper, because of a slight difference in the air inflow through the burning cone during a puff and the combustion of TPM accumulated on the tobacco of the butt. However, the values of $C_{0}$ and $C_{p}$ can be regarded as average values per puff. Therefore, the total delivery of gas compo- 
Figure 1.

A typlcal relationshlp between the logarithmlc value of gas concentration and the butt length In contact with alr (cigarette circumference: $25 \mathrm{~mm}$ ).

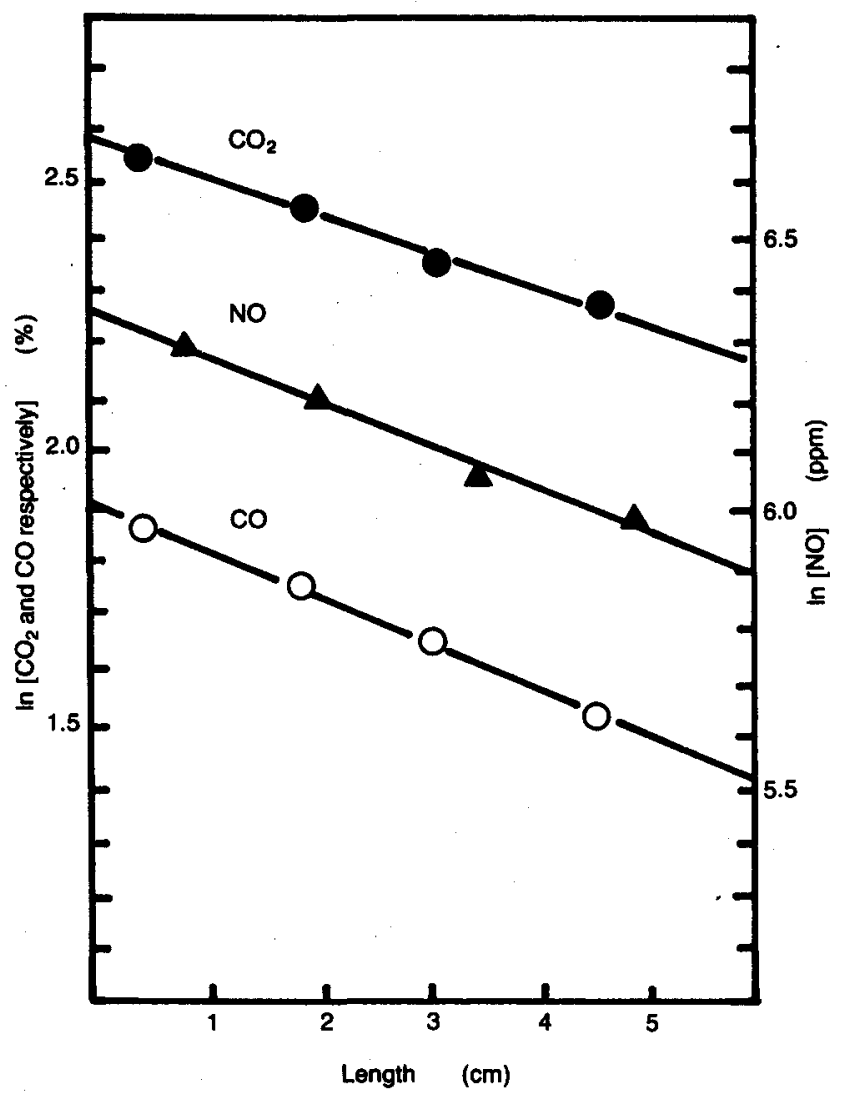

nents per cigarette can be expressed as $\mathrm{nC}_{\mathrm{p}}$, where $\mathrm{n}$ is the puff count. The total delivery of vapour phase $\mathrm{CH}_{3} \mathrm{CHO}$ was considered to be almost equal to that in the mainstream smoke, because, in the vapour phase, it neither diffuses through the cigarette paper nor is retained by the filter. The total delivery of $B[a] P$ was obtained from the sum of the amount in the mainstream smoke and that retained by the filter which was measured directly. The total delivery of HCN was taken to be the same as that in the mainstream smoke of a nonfilter cigarette which was smoked up to a butt length of $1 \mathrm{~cm}$. In that case, the amount of $\mathrm{HCN}$ retained by the tobacco column could be ignored, because the retention of $\mathrm{HCN}$ in the particulate phase by the tobacco column was very small.

\section{RESULTS AND DISCUSSIONS}

\section{Amount of Components in Mainstream Smoke}

Figure 2 shows the amounts of $\mathrm{CO}, \mathrm{CO}_{2}, \mathrm{NO}$ and vapour phase $\mathrm{CH}_{3} \mathrm{CHO}$ in mainstream smoke. With increasing circumference, each component increased. In the range from $21 \mathrm{~mm}$ to $26 \mathrm{~mm}$, the increase was about $20 \%$ for $\mathrm{CO}, 40 \%$ for $\mathrm{CO}_{2}, 43 \%$ for $\mathrm{NO}$ and $57 \%$ for vapour phase $\mathrm{CH}_{3} \mathrm{CHO}$. On the other hand,
Figure 2.

The amounts of $\mathrm{CO}, \mathrm{CO}_{2}$, $\mathrm{NO}$ and vapour phase $\mathrm{CH}_{3} \mathrm{CHO}$ in mainstream smoke vs. clgarette clrcumference.

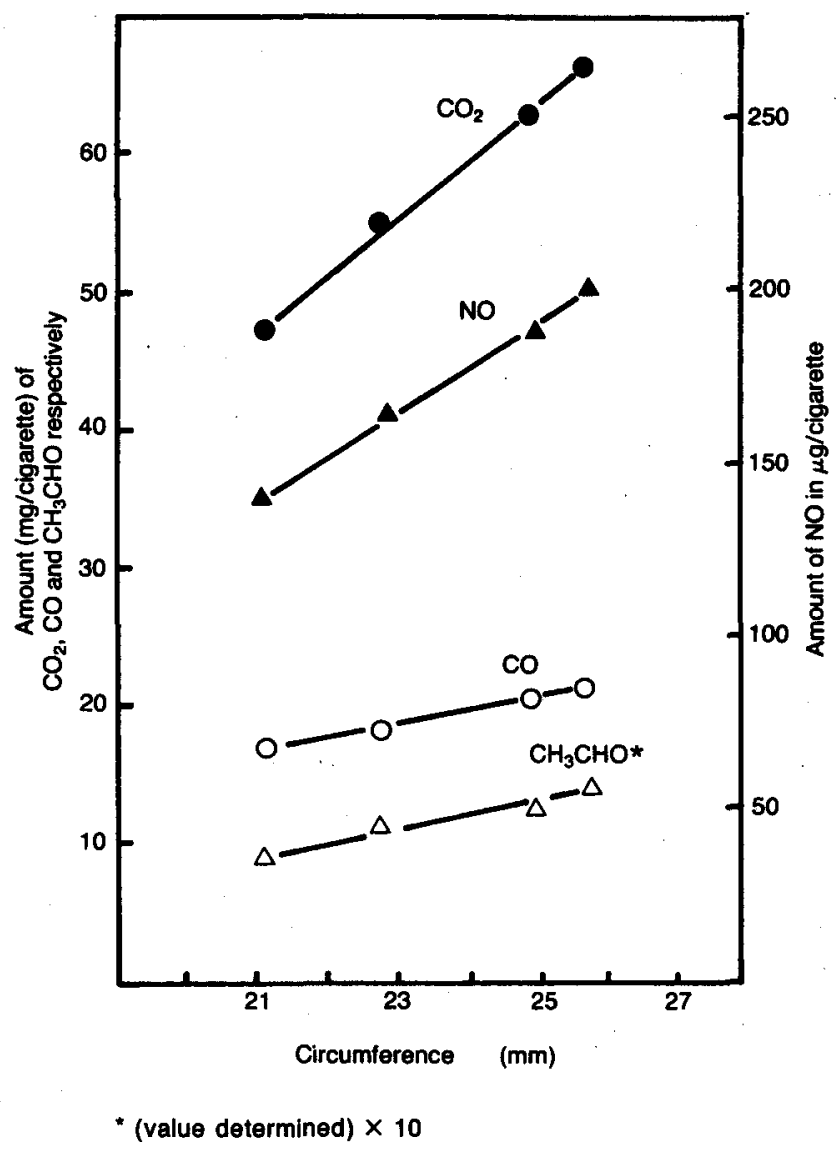

as shown in Figure 3, the effect of circumference on the amounts of $B[a] P$ and $H C N$ was found to be different from that on the components shown in Figure 2. With increasing circumference, not only did the amount of $\mathrm{B}[\mathrm{a}] \mathrm{P}$ increase, but the rate of increase also became higher. The amount of $\mathrm{HCN}$ was almost constant, not depending on changes in circumference. To clarify the reason for these different patterns, the following experiments were carried out.

\section{Total Deliveries of Smoke Components}

Table 2 shows the amounts of $\mathrm{CO}, \mathrm{CO}_{2}$ and $\mathrm{NO}$ formed during a puff $\left(\mathrm{C}_{\mathrm{p}}\right)$, which were derived from $\mathrm{C}_{0}$. The total deliveries of these gas components can be expressed as $\mathrm{nC}_{\mathrm{p}}$, where $\mathrm{n}$ is the puff count. The total delivery of vapour phase $\mathrm{CH}_{3} \mathrm{CHO}$ is almost equal to that in the mainstream smoke as described in the section Materials and Methods. Figures 4 and 5 show the total deliveries of these gas components $\left(\mathrm{nC}_{\mathrm{p}}\right)$, and those of $\mathrm{B}[a] \mathrm{P}$ and $\mathrm{HCN}$ vs. the weight loss of tobacco during puffs which can be expressed as $n W_{p}$, where $W_{p}$ is the weight loss during one puff (1). The total delivery of tar and $n W_{p}$ were already reported to be proportional to the square of the radius of a cigarette (1). The total deliveries of $\mathrm{CO}_{2}, \mathrm{NO}$ and vapour phase 
Table 2.

Concentration and amount of gas components during a puff.

\begin{tabular}{c|ccc|ccc}
\hline \multirow{2}{*}{ Circumference } & \multicolumn{3}{|c|}{$\begin{array}{c}\text { Concentration of gas } \\
\text { formed during a puff }\left(\mathrm{C}_{0}\right)\end{array}$} & \multicolumn{3}{c}{$\begin{array}{c}\text { Amount of gas } \\
\text { formed during a puff }\left(\mathrm{C}_{\mathrm{p}}\right)\end{array}$} \\
\cline { 2 - 7 }$(\mathrm{mm})$ & $\begin{array}{c}\mathrm{CO} \\
(\%)\end{array}$ & $\begin{array}{c}\mathrm{CO}_{2} \\
(\%)\end{array}$ & $\begin{array}{c}\mathrm{NO} \\
(\mathrm{ppm})\end{array}$ & $\begin{array}{c}\mathrm{CO} \\
(\mathrm{mg})\end{array}$ & $\begin{array}{c}\mathrm{CO}_{2} \\
(\mathrm{mg})\end{array}$ & $\begin{array}{c}\mathrm{NO} \\
(\mu \mathrm{g})\end{array}$ \\
\hline 21.1 & 6.20 & 10.88 & 489.4 & 2.51 & 6.92 & 21.22 \\
22.9 & 6.15 & 12.10 & 504.7 & 2.49 & 2.70 & 2.89 \\
25.0 & 6.67 & 12.87 & 574.0 & 2.70 & 8.19 & 24.89 \\
25.8 & 6.68 & 13.40 & 595.8 & 2.70 & 8.52 & 25.84 \\
\hline
\end{tabular}

Figure 3.

The amounts of B[a]P and HCN In mainstream smoke v8. cigarette clrcumference.

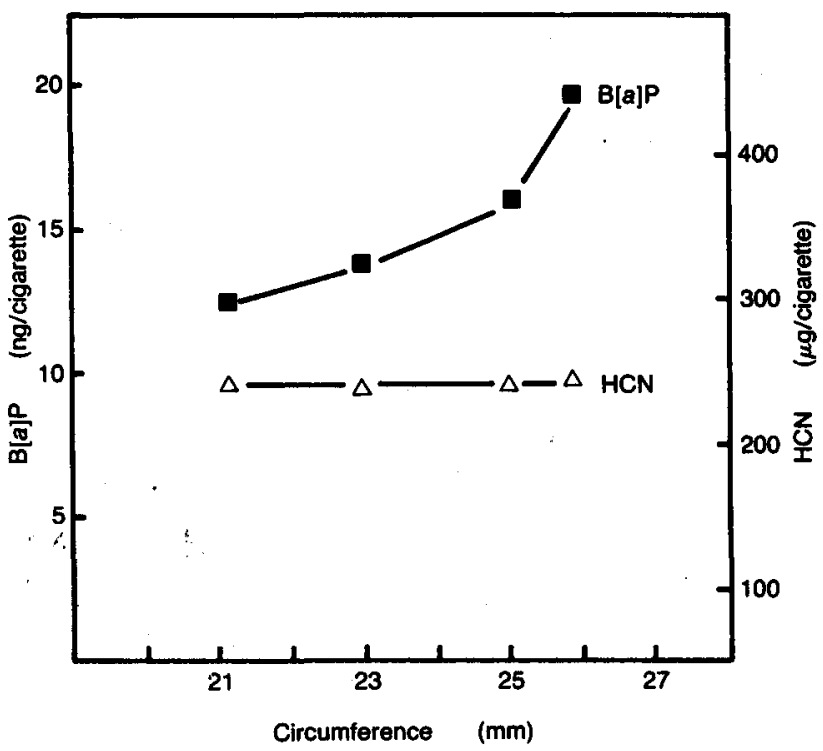

Flgure 4.

Total dellvery of $\mathrm{CO}, \mathrm{CO}_{2}$, NO and vapour phase $\mathrm{CH}_{3} \mathrm{CHO}$ vs. weight loss of tobacco during putfs.
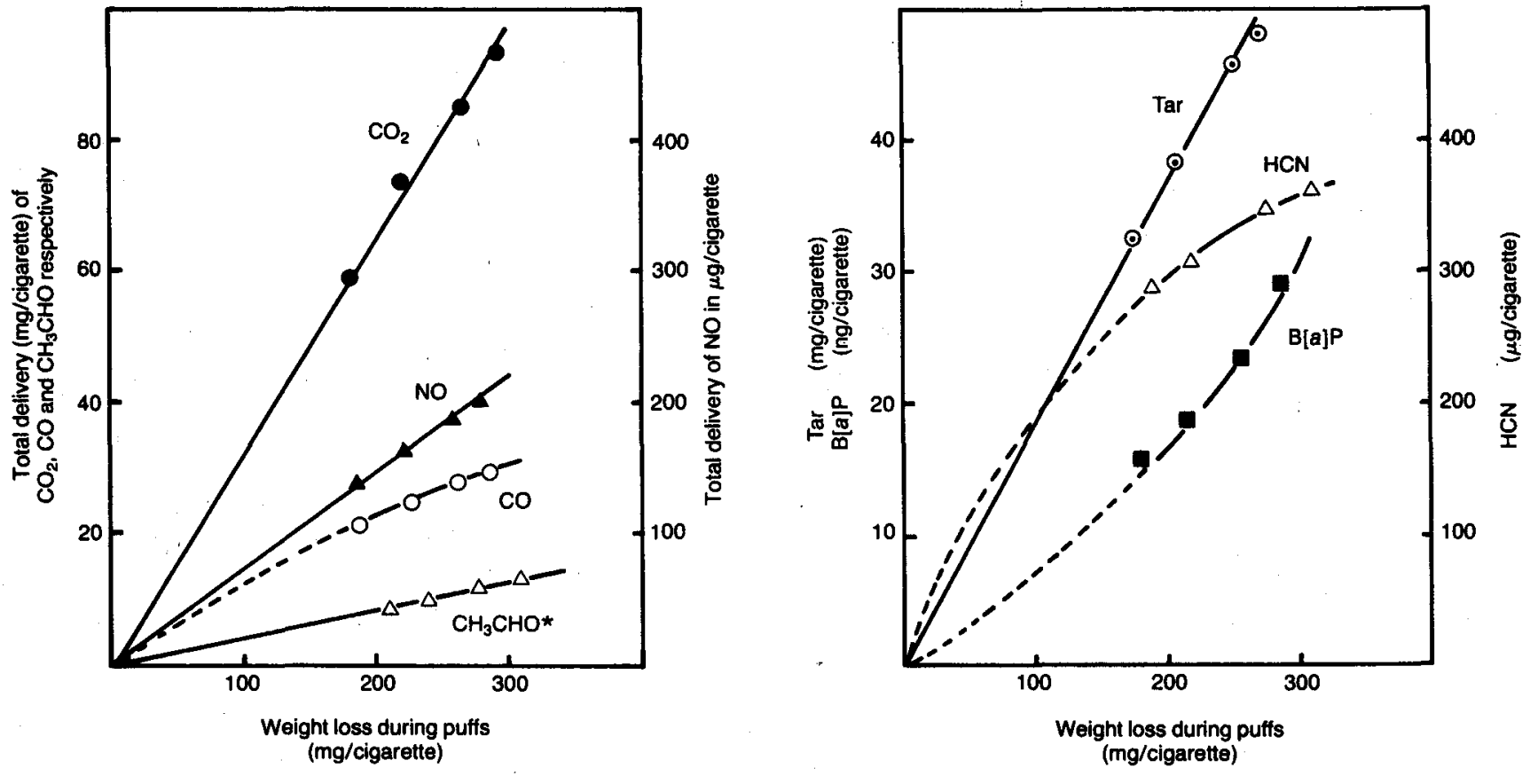

"(value determined) $\times 10$ 
Table 3.

Effect of cigarette circumference on the diffuslon of gas components.

\begin{tabular}{c|ccc|ccc}
\hline \multirow{2}{*}{\begin{tabular}{c} 
Circumference \\
\cline { 2 - 7 }
\end{tabular}} & \multicolumn{3}{|c|}{ Amount lost through diffusion } & \multicolumn{3}{c}{ Diffusion rate } \\
\cline { 2 - 7 } & $\begin{array}{c}\mathrm{CO} \\
(\mathrm{mg} / \mathrm{cig})\end{array}$ & $\begin{array}{c}\mathrm{CO}_{2} \\
(\mathrm{mg} / \mathrm{cig})\end{array}$ & $\begin{array}{c}\mathrm{NO} \\
(\mu \mathrm{g} / \mathrm{cig} .)\end{array}$ & $\begin{array}{c}\mathrm{CO} \\
(\%)\end{array}$ & $\begin{array}{c}\mathrm{CO}_{2} \\
(\%)\end{array}$ & $\begin{array}{c}\text { NO } \\
(\%)\end{array}$ \\
\hline 21.1 & 4.24 & 11.10 & 39.81 & 19.9 & 18.9 & 22.1 \\
22.9 & 6.14 & 20.20 & 40.99 & 25.4 & 27.0 & 19.7 \\
25.0 & 7.60 & 22.56 & 66.69 & 27.1 & 26.5 & 26.3 \\
25.8 & 8.93 & 27.07 & 76.03 & 30.1 & 28.9 & 27.5 \\
\hline
\end{tabular}

$\mathrm{CH}_{3} \mathrm{CHO}$ were found to be proportional to $\mathrm{nW}$ (Figure 4). The plot of $\mathrm{CO}$ did not fall on a straight line passing through the origin, showing that the rate of increase decreased slightly with increasing $\mathrm{nW}_{\mathrm{p}}$. As shown in Figure 5, the total deliveries of $B[a] P$ and $\mathrm{HCN}$ were not proportional to $n W_{p}$, i.e. the rate of change in $B[a] P$ became greater and that of $\mathrm{HCN}$ lower with increasing $\mathrm{nW}_{\mathrm{p}}$.

From the total delivery of gas components and the amount in the mainstream smoke, the loss through diffusion from the cigarette paper was estimated. These data are shown in Table 3. The amount lost through diffusion increased with increasing circumference. The diffusion rate, which was calculated from the ratio of the amount lost through diffusion to the total delivery, also increased with increasing circumference. The diffusion rate of NO remained almost equal to that of $\mathrm{CO}$ for the various circumferences.

Figure 6 shows a decrease in the retention of $\mathrm{B}[a] \mathrm{P}$ and HCN by the filter with decreasing circumference. The retention of these components was lower than that of tar obtained from the same cigarette samples (1). The decrease in $\mathrm{HCN}$ retention with decreasing circumference was sharper than that for tar or $\mathrm{B}[a] \mathrm{P}$. It is well known that $\mathrm{HCN}$ formed during puffs is distributed in both the vapour and particulate phases $(9,10)$. The sharp decrease in $\mathrm{HCN}$ retention is thought to be a result of a decrease in the condensation of gaseous $\mathrm{HCN}$ which, in turn, is due to an increase in the velocity of air in the tobacco filter when the circumference is reduced.

\section{Formation Rate of Smoke Components}

Figures 4 and 5 show the difference in the effect of circumference on the rates of formation of these components, since the gradient at each point corresponds to the formation rate. The rates of formation of $\mathrm{CO}_{2}, \mathrm{NO}$ and vapour phase $\mathrm{CH}_{3} \mathrm{CHO}$, as well as tar, were found to be almost constant and independent of circumference. On the other hand, the rate of formation of $\mathrm{CO}$ increased slightly, HCN increased considerably, and $\mathrm{B}[\mathrm{a}] \mathrm{P}$ decreased with decreasing circumference. The results can be attributed to the difference in the formation mechanisms of these components during puffs. $\mathrm{NO}$ and vapour phase $\mathrm{CH}_{3} \mathrm{CHO}$ in mainstream smoke are mostly formed from the thermal decomposition of tobacco during puffs, the former from nitrate $(11-14)$, the latter from skeleton substances such as cellulose (15-17). The independence of circumference of the rates of formation of $\mathrm{NO}$ and vapour phase $\mathrm{CH}_{3} \mathrm{CHO}$ can be explained by the fact that formation of these components by thermal decomposition occurs in the range of temperatures below about $400^{\circ} \mathrm{C}$, which coincides with the loss in weight of the tobacco. The independence of the rate of formation of $\mathrm{CO}_{2}$ of circumference seems to be due to the fact that $\mathrm{CO}_{2}$ is a primary product formed by both thermal decomposition and combustion of tobacco, and that an endothermic reduction of $\mathrm{CO}_{2}$ to $\mathrm{CO}$ occurs in the range of combustion temperatures.

The formation of $\mathrm{HCN}$ from nitrogen substances, such as protein, amino acids and nitrate, is known to be promoted by an increase in temperature $(18,19)$. With increasing combustion temperature, the ratio of $\mathrm{CO}$ to $\mathrm{CO}_{2}$ becomes higher owing to enhancement of the carbonaceous reduction of $\mathrm{CO}_{2}$ to $\mathrm{CO}(20-23)$, and to higher activation energy for $\mathrm{CO}$ formation than that

Figure 6.

Effect of circumference on retention of tar, B[a]P and HCN by the filter.

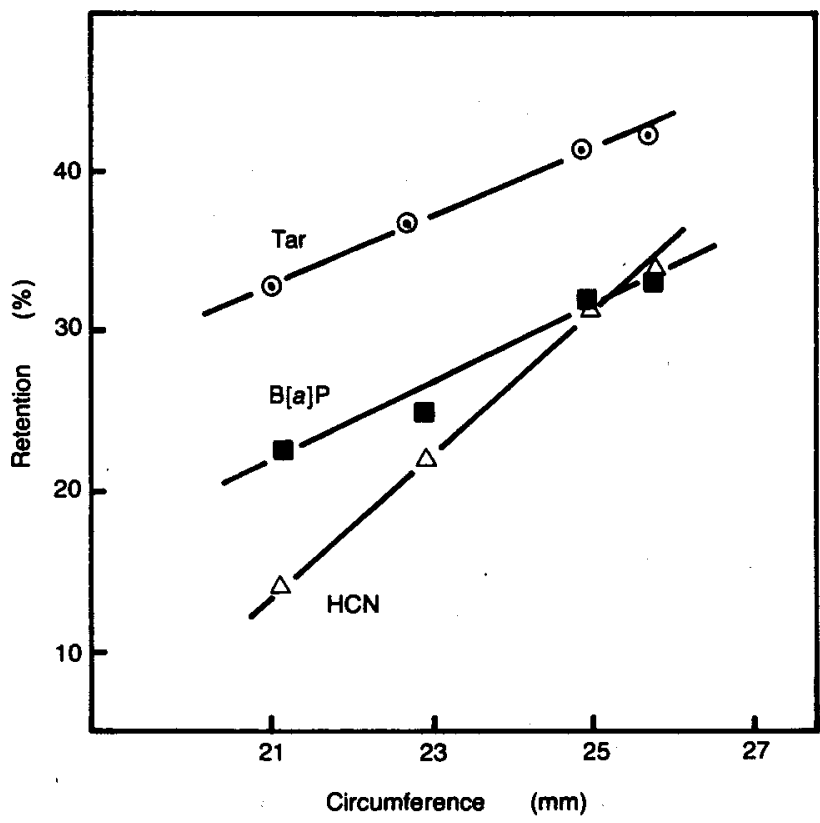


Flgure 7.

Effect of circumference on total dellvery of $\mathrm{CO} / \mathrm{CO}_{2}$.

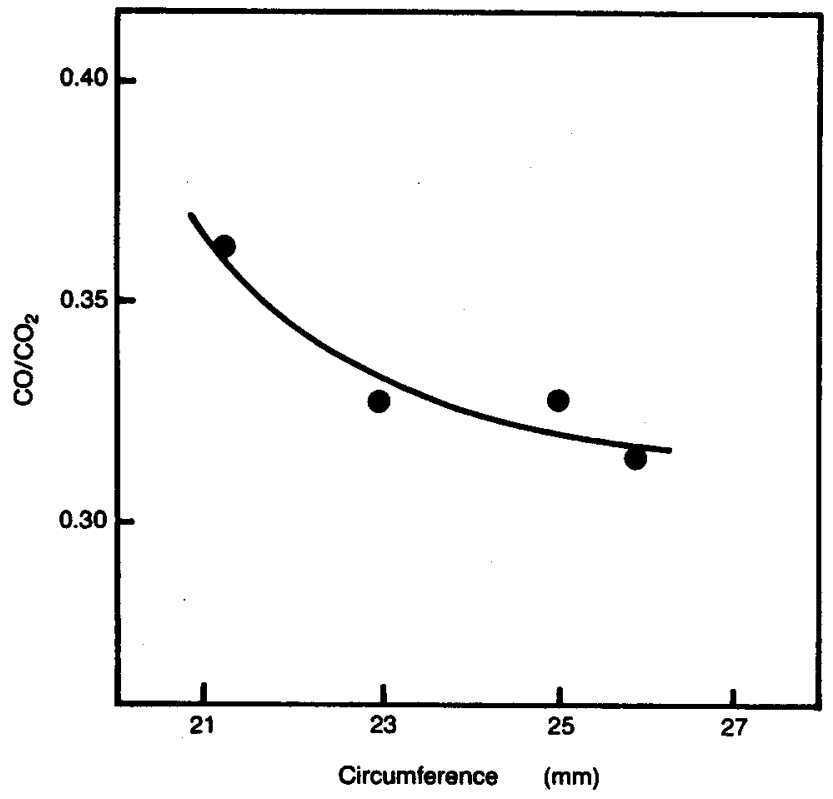

for $\mathrm{CO}_{2}$ formation in oxidative reaction $(21,22)$. In the present experiment, the ratio of total delivery of $\mathrm{CO}$ to that of $\mathrm{CO}_{2}$ increased with decreasing circumference (Figure 7). This is thought to be caused by the following phenomenon: with decreasing circumference the ratio of air inflow through the burning cone to the amount of tobacco consumed during a puff becomes higher, because the weight loss of tobacco during a puff changes proportionally with circumference (1). Consequently, it seems reasonable to conclude that the increase in the rate of formation of $\mathrm{CO}$ and $\mathrm{HCN}$ resulted from an increase in the combustion temperature due to a decrease in circumference. In addition, there seems to be some connection between the rate of formation of $B[a] P$ and the combustion temperature. An increase in the concentration of $\mathrm{B}[\mathrm{a}] \mathrm{P}$ (the ratio of $\mathrm{B}[\mathrm{a}] \mathrm{P}$ to tar) has been found in cigarettes with a vented filter (24). Increasing the ventilation of a cigarette can reduce the maximum solid-phase temperature at the base of the cone $(20,25)$, and decrease the ratio of $\mathrm{CO}$ to $\mathrm{CO}_{2}(22,26)$. Hence, the increase in the formation rate for $B[a] P$ is thought to be due to a decrease in the temperature of the burning cone during puffs. From these results and discussion, we can ascribe the reason for differences in the effect of circumference between the amounts of $\mathrm{B}[\mathrm{a}] \mathrm{P}$ and $\mathrm{HCN}$ in the mainstream smoke (Figure 3) to distinction in their formation rate during puffs and retention by the filter. The increase in the amount of $B[a] P$ in mainstream smoke as well as its ascending rate of change with increasing circumference can be explained by an increase in the rate of formation which results in a sharp increase in total delivery. The almost constant amount of $\mathrm{HCN}$ in mainstream smoke in the range from $21 \mathrm{~mm}$ to $26 \mathrm{~mm}$ of circumference can be explained by a sharp decrease in retention by the filter and an increase in the rate of formation of $\mathrm{HCN}$ with decreasing circumference.

\section{REFERENCES}

1. Yamamoto, T., U. Anzai and T. Okada: Effect of cigarette circumference on weight loss during puffs and total delivery of tar and nicotine; Beitr. Tabakforsch. Int. 12 (1984) 259-269.

2. Maeda, K., F. Kondo, A. Tokida and K. Noguchi: Effect of the degree of perforation of cigarette paper and tipping paper on the performance of filter cigarette, IV. On the reduction of the main vapor phase components in cigarette smoke; Jpn. Monop. Corp. Cent. Res. Inst. Sci. Pap. 120 (1978) 51-60.

3. Matsumoto, T., Y. Suga and T. Tomita: unpublished.

4. Epstein, J.: Estimation of microquantities of cyanide; Anal. Chem. 19 (1947) 202-204.

5. Owen, W. C., and M. L. Reynolds: The diffusion of gases through cigarette paper during smoking; Tob. Sci. 11 (1967) 14-20.

6. Morie, G. P.: Some factors that affect the diffusion of carbon monoxide out of cigarettes; Tob. Sci. 20 (1976) 174-176.

7. Baker, R. R., and R. A. Crellin: The diffusion of carbon monoxide out of cigarettes; Beitr. Tabakforsch. 9 (1977) 131-140.

8. Muramatsu, M., T. Mikami, N. Naitō and H. Tomita: A model study on the diffusion and the dilution of low molecular weight gaseous components through cigarette paper during smoking; Beitr. Tabakforsch. 9 (1977) 141-146.

9. Rathkamp, G., T. C. Tso and D. Hoffmann: Chemical studies on tobacco smoke, XX. Smoke analysis of cigarettes made from Bright tobaccos differing in variety and stalk positions; Beitr. $\mathrm{T}_{2}$ bakforsch. 7 (1973) 179-189.

10. Klus, $H$., and $H$. Kuhn: Verteilung verschiedener Tabakrauchbestandteile auf Haupt- und Nebenstromrauch (Eine Übersicht); Beitr. Tabakforsch. Int. 11 (1982) 229-265.

11. Johnson, W. R., R. W. Hale, S. C. Clough and P. $\mathrm{H}$. Chen: Chemistry of the conversion of nitrate to smoke products; Nature 243 (1973) 223-225.

12. Williams, T. B.: The determination of nitric oxide in gas phase cigarette smoke by non-dispersive infrared analysis; Beitr. Tabakforsch. Int. 10 (1980) 91-99.

13. Brunnemann, K. D., and D. Hoffmann: Pyrolytic origins of major gas phase constituents of cigarette smoke; Recent Advances in Tobacco Science 8 (1982) 103-140.

14. Umemura, S., M. Muramatsu and T. Okada: A study on precursors of nitric oxide in sidestream smoke; Beitr. Tabakforsch. Int. Vol. 13, in the press.

15. Kaburaki, Y., H. Shigematsu and H. Kusakabe: Studies on the composition of tobacco smoke, X. Relation between vapor phase components of smoke and constituents of tobacco; Jpn. Monop. Corp. Cent. Res. Inst. Sci. Pap. 111 (1969) 135142. 
16. Kato, K: Pyrolysis of cellulose, III. Comparative studies of the volatile compounds from pyrolysates of cellulose and its related compounds; Agric. Biol. Chem. 31 (1967) 657-663.

17. Kusama, M., H. Sakuma and S. Sugawara: Low boiling compounds in cellulose cigarette smoke; Agric. Biol. Chem. 42 (1978) 479-481.

18. Johnson, W. R., and J. C. Kang: Mechanisms of hydrogen cyanide formation from the pyrolysis of amino acids and related compounds; J. Org. Chem. 36 (1971) 189-192.

19. Johnson, W. R., J. W. Nedlock and R. W. Hale: Mechanisms of the pyrolysis of poly(amino acid); Tob. Sci. 17 (1973) 89-92.

20. Baker, R. R.: Mechanisms of smoke formation and delivery; Recent Advances in Tobacco Science 6 (1980) 184-224.

21. Baker, R, R.: Formation of carbon oxides during tobacco combustion - Pyrolysis studies in the presence of isotopic gases to elucidate reaction sequence; J. Anal. Appl. Pyrolysis 4 (1983) 297-334.

22. Baker, R. R.: The effect of ventilation on cigarette combustion mechanisms; Recent Advances in Tobacco Science 10(1984) 88-150.
23. Muramatsu, M., S. Umemura and T. Okada: Consumption of oxygen and heat evolved during natural smoulder of cigarette; J. Chem. Soc. Japan 10 (1978) 1441 - 1448.

24. Suga, Y.: unpublished data.

25. Lendvay, A. T., and T. S. Laszlo: Cigarette peak coal temperature measurements; Beitr. Tabakforsch. 7 (1974) 276-281.

26. Browne, C. L., C. H. Keith and R. E. Allen: The effect of filter ventilation on the yield and composition of mainstream and sidestream smokes; Beitr. Tabakforsch. Int. 10 (1980) 81-90.

Authors' address:

Central Researcb Institute,

Japan Tobacco Inc., 6-2 Umegaoka, Midori-ku, Yokohama, Kanagawa, 227, Japan. 